\title{
TGF-beta signalling in bovine mammary gland involution and a comparative assessment of MAC-T and BME-UV1 cells as in vitro models for its study
}

\author{
Charlotte Alexandra Mitz ${ }^{1}$, Alicia Mercedes Viloria-Petit ${ }^{\text {Corresp. } 1}$ \\ 1 Department of Biomedical Sciences, Ontario Veterinary College, University of Guelph, Guelph, Ontario, Canada \\ Corresponding Author: Alicia Mercedes Viloria-Petit \\ Email address: aviloria@uoguelph.ca
}

The goal of the dairy industry is ultimately to increase lactation persistency, which is the length of time during which peak milk yield is sustained. Lactation persistency is determined by the balance of cell apoptosis and cell proliferation; when the balance is skewed toward the latter, this results in greater persistency. Thus, we can potentially increase milk production in dairy cows through manipulating apoptogenic and antiproliferative cellular signalling that occurs in the bovine mammary gland. Transforming growth factor beta 1 (TGF $\beta 1$ ) is an antiproliferative and apoptogenic cytokine that is upregulated during bovine mammary gland involution. Here we discuss possible applications of TGF $\beta 1$ signalling for the purposes of increasing lactation persistency. We also compare the features of MAC-T and BME-UV1 cells, two popular bovine mammary epithelial cell lines, to assess their appropriateness for the study of TGF $\beta 1$ signalling. TGF 1 induces apoptosis and arrests cell growth in BME-UV1 cells, and this was reported to involve suppression of the somatotropic axis. Conversely, there is no proof that exogenous TGF $\beta 1$ induces apoptosis of MAC-T cells.In addition to TGF $\beta 1$ 's different effects on apoptosis, hormones and growth factors have distinct effects on TGF $\beta 1$ secretion and synthesis in MAC-T and BME-UV1 cell lines. MAC-T and BME-UV1 cells may behave differently in response to TGF $\beta 1$ due to their contrasting phenotypes; MAC-T cells have a profile indicative of both myoepithelial and luminal populations, while the BME-UV1 cells exclusively contain a luminal-like profile. Depending on the nature of the research question, the use of these cell lines as models to study TGF $\beta 1$ signalling should be carefully tailored to the questions asked. 
1 TGF-beta signalling in bovine mammary gland involution 2 and a comparative assessment of MAC-T and BME-UV1

3 cells as in vitro models for its study

4 Charlotte Alexandra Mitz ${ }^{1}$ and Alicia Mercedes Viloria-Petit ${ }^{1}$

$5{ }^{1}$ Department of Biomedical Sciences, Ontario Veterinary College, University of Guelph,

6 Guelph, ON, Canada

7 Corresponding Author:

8 Alicia Viloria-Petit

9 Email address: aviloria@uoguelph.ca 
The goal of the dairy industry is ultimately to increase lactation persistency, which is the

12 length of time during which peak milk yield is sustained. Lactation persistency is determined by

13 the balance of cell apoptosis and cell proliferation; when the balance is skewed toward the latter,

14 this results in greater persistency. Thus, we can potentially increase milk production in dairy

15 cows through manipulating apoptogenic and antiproliferative cellular signalling that occurs in

16 the bovine mammary gland. Transforming growth factor beta 1 (TGF $\beta 1$ ) is an antiproliferative

17 and apoptogenic cytokine that is upregulated during bovine mammary gland involution. Here we

18 discuss possible applications of TGF $\beta 1$ signalling for the purposes of increasing lactation

19 persistency. We also compare the features of MAC-T and BME-UV1 cells, two popular bovine

20 mammary epithelial cell lines, to assess their appropriateness for the study of TGF $\beta 1$ signalling.

21 TGF $\beta 1$ induces apoptosis and arrests cell growth in BME-UV1 cells, and this was reported to

22 involve suppression of the somatotropic axis. Conversely, there is no proof that exogenous

23 TGF $\beta 1$ induces apoptosis of MAC-T cells. In addition to TGF $\beta 1$ 's different effects on apoptosis,

24 hormones and growth factors have distinct effects on TGF $\beta 1$ secretion and synthesis in MAC-T

25 and BME-UV1 cell lines. MAC-T and BME-UV1 cells may behave differently in response to

26 TGF $\beta 1$ due to their contrasting phenotypes; MAC-T cells have a profile indicative of both

27 myoepithelial and luminal populations, while the BME-UV1 cells exclusively contain a luminal-

28 like profile. Depending on the nature of the research question, the use of these cell lines as

29 models to study TGF $\beta 1$ signalling should be carefully tailored to the questions asked. 
The dairy industry could gain significant financial advantage by extending the

32 persistency of lactation (Capuco et al., 2003), which is defined as the number of days in which a constant milk yield is maintained (Grossman, Hartz \& Koops, 1999). One of the ways in which dairy farmers increase milk yield is through exogenous administration of recombinant bovine growth hormone $(\mathrm{rBGH})$, which is also known as recombinant bovine somatotropin (rBST) (Etherton and Bauman, 1998). While the use of this hormone presents no health concerns to humans (MacLeod et al., 1999), it is costly to the health of dairy cows (Dohoo et al., 2003). To assess the impact of $\mathrm{rBGH} / \mathrm{rBST}$ on animal health, a meta-analysis was conducted by the to dairy cows increased the risk of clinical mastitis by up to $25 \%$, of infertility by $40 \%$, and of lameness by up to 55\% (Dohoo et al., 2003). The use of $\mathrm{rBGH} / \mathrm{rBST}$ has been banned in Canada,

42 however this hormone is commonly used on dairy cows in the United States (Forge, 1998; Sechen, 2013). BGH/BST is considered the predominant galactopoietic hormone in dairy cows (Tucker, 2000) and based on studies in rodents (Collier, Annen-Dawson \& Pezeshki, 2012) and in bovine mammary gland explants (Palin, Farmer \& Duarte, 2017), BGH/BST acts in conjunction with the well-documented galactopoietic hormone, prolactin (PRL). Many of the galactopoietic effects of BGH/BST are thought to be mediated through insulin-like growth factor I (IGF-I; Bauman, 1999). Binding of IGF-I to the IGF receptor (IGFR) activates IGFR intrinsic tyrosine kinase activity, and leads to the activation of the phosphatidylinositol-4,5-biphosphate $\underline{3}$ kinase (PI3K)/Akt (Argetsinger et al., 1993). In this review, we will refer to this BGH/IGF1/PI3K/Akt signalling pathway as the somatotropic axis. One of the ways that IGF-I enhances survival is through suppression of the cytokine transforming growth factor beta $\underline{1}$ (TGF $\beta 1$; 
53 Gajewska and Motyl, 2004). MAC-T (mammary alveolar cells expressing SV-40 large $\underline{\mathrm{T}}$

54 antigen) and BME-UV1 (ㅁovine mammary eppithelial cells- clone UV1) are two of the most

55 popular immortalized bovine mammary epithelial cell lines used in the study of mammalian

56 lactation (Jedrzejczak and Szatkowska, 2014). TGF $\beta 1$ induces apoptosis and arrests cell growth

57 of BME-UV1 cells, and this was reported to involve suppression of the somatotropic axis (Kolek

58 et al., 2003; Gajewska and Motyl, 2004). Interestingly, there is no literature to support that

59 exogenous TGF $\beta 1$ induces apoptosis of MAC-T cells, nor suppresses the somatotropic pathway.

60 In this article, we present an overview of TGF $\beta$ signaling in the bovine mammary gland, we

61 review and compare the literature on the

62 MACT-T and BME-UV1 cell lines, and we provide possible explanations as to why

63 different responses to TGF $\beta 1$ are observed. We also provide suggestions along the way that

64 might aid in improving our understanding TGF $\beta$ function $\square \square$ the bovine mammary gland, as

65 well as potential means to alter TGF $\beta$ signalling as a way of increasing milk production.

66

67

68

69 70

\section{SURVEY METHODOLOGY}

Relevant journal articles were obtained by performing a search for "MAC-T TGFbeta", "BME-UV1 TGFbeta", "Bovine mammary TGFbeta", "Bovine mammary epithelial TGFbeta", and "Bovine mammary stroma TGFbeta"on the databases Web of Science, Google Scholar, PubMed and JSTOR. 

transitions from a lactating to a non-lactating state (Hurley, 1989), and is also the initiation of the dry period. The dry period is a term used in the dairy industry and is defined as the period between cessation of milk removal at dry-off and the initiation of milking at the subsequent calving (Hurley and Loor, 2011). In bovine mammary gland involution, there is a decline in systemic hormone (e.g., BGH/BST and PRL) levels, and this is thought to initiate apoptosis of senescent secretory epithelial cells (Pai and Horseman, 2011). These secretory epithelial cells surround the lumen of the alveoli connected to a basement membrane, and are themselves surrounded by a layer of contractile myoepithelial cells (Nickerson and Akers, 2011). During lactation, secretory epithelial cells are responsible for synthesizing and secreting milk into the lumen, which is then drained into the ducts and collected by the lactiferous sinus before milk removal (Nickerson and Akers, 2011). The role of myoepithelial cells is to contract to allow the secretory epithelial cells to secrete milk out of the lumen and into the ducts (Bruckmaier and Blum, 1998). They are also important for the establishment of apical-basal polarity and for cellular survival, as they secrete components of the basement membrane, which by binding integrins on the basal site of luminal epithelial cells, activate cellular signalling that direct these events (Weaver et al., 2002).

9033 members, where TGF $\beta \square \square \square \square \square \square$ exists in three different isoforms, TGF $\beta 1,2$ and 3

91 (Gilbert, Vickaryous \& Viloria-Petit, 2016). TGF $\beta 1$ plays a key role in bovine mammary gland

92 involution by inducing apoptosis and autophagy in bovine mammary luminal epithelial cells

93 (Kolek et al., 2003; Gajewska, Gajkowska \& Motyl, 2005; Zarzyńska, Gajewska \& Motyl, 
94 2005). Our review of the bovine literature did not yield any reports of TGF $\beta 1$ 's effects on

95 myoepithelial cells, specifically. Unlike some other species, alveolar structures remain intact and

96 secretory epithelial and myoepithelial cells remain in the same position throughout bovine

97 mammary involution and the dry period (Holst, Hurley \& Nelson, 1987). Morphologically,

98 bovine involution is characterized by reduced alveolar lumen area (Holst, Hurley \& Nelson,

99 1987), as well as reduced integrity and increased permeability of tight junctions (Pai and

100 Horseman, 2011). Polarized human and murine mammary luminal epithelial cells with well-

101 established tight and adherens junctions as well as hemidesmosomes are resistant to apoptosis

102 (Weaver et al., 2002; Avery-Cooper et al., 2014), and this might be the case for bovine

103 mammary epithelial cells, as supported by a study by Singh et al. (2005) demonstrating that cell-

104 ECM communication is important in regulating bovine mammary epithelial cell survival. In

105 other species such as mice, TGF $\beta 1$ is reported to dysregulate tight junctions causing mammary

106 epithelial cells to undergo apoptosis (Avery-Cooper et al., 2014). Whether TGF $\beta 1$ disrupts tight

107 junctions in the bovine mammary gland, and whether this is responsible for TGF $\beta 1$-induced

108 apoptosis in the involuting bovine mammary gland, remains to be addressed.

109 TGF $\beta 1$ and its receptors are upregulated during bovine involution (Plath et al., 1997), and

110 in vitro findings suggest that elevated TGF $\beta 1$ expression during involution is due in part to its

111 increased secretion by bovine mammary cells during the transition from lactation to the dry

112 period (Zarzyńska, Gajewska \& Motyl, 2005), as well as through enhanced release of TGFß1

113 from the extracellular matrix (ECM) (De Vries et al., 2011). TGF $\beta 1$ arrests bovine epithelial cell

114 growth (Kolek et al., 2003) and such effect of TGF $\beta 1$ was shown to be important for the

115 development of fully functional mammary glands in mice. In particular, TGF $\beta 1$ inhibited ductal

116 branching and lateral extension via induction of Wnt5a expression and release (Roarty and Serra, 
117 2007), and thus is currently considered a major regulator of ductal patterning in the mammary

118 gland. It is unclear whether other isoforms, in addition to TGF $\beta 1$, are involved in lactation and/or

119 involution in the bovine mammary gland. In this review, we focus specifically on the TGF $\beta 1$

120 isoform because it is the most commonly studied in the literature, but it is important to note that

121 all three isoforms are present and differentially expressed in the bovine mammary gland (Maier

122 et al., 1991). TGF $\beta 1$ and TGF $\beta 3$ are expressed by both the alveolar epithelium and the

123 subepithelial stroma, while TGFß2 is only expressed in epithelial cells (Maier et al., 1991).

124 Bovine studies involving TGF $\beta 3$ should be encouraged in the future, given its demonstrated role

125 in the involuting murine mammary gland, including repression of mammary luminal epithelial

126 cell differentiation via induction of apoptosis (Nguyen \& Pollard, 2000), and clearance of the

127 dead epithelial cells via induction of phagocytic activity in the neighboring epithelial cell

128 survivors (Fornetti et al., 2016).

129 In recent years, there has been a greater research focus on the mammary stroma and its

130 influence on epithelial function. The stroma primarily consists of adipocytes and fibroblasts, but

131 also contains endothelial cells, ECM, and inflammatory cells (Kass et al., 2007). TGF $\beta 1$ is a

132 potent mediator of ECM synthesis and protects the ECM from degradation (Lasky and Brody,

133 2000; Woodward et al., 2005). Moderate amounts of fibrous tissue is a normal component of the

134 involuting bovine mammary gland, and plays a major role in remodeling and in preparing the

135 gland for the subsequent lactation period (De Vries et al., 2010). However, excessive TGF $\beta 1$

136 correlates with extensive tissue fibrosis, and this can interfere with the normal function of the

137 bovine mammary gland, namely milk production (Andreotti et al., 2014). Excessive tissue

138 fibrosis characterizes bovine mastitis (Andreotti et al., 2014), which is defined as inflammation

139 of the mammary gland, and this is a major cause of financial losses to the dairy industry 
140 (Heikkilä et al., 2012). Furthermore, TGF $\beta 1$ is overexpressed in mastitic mammary glands in

141 parallel with increased fibrosis and apoptosis of epithelial cells (Andreotti et al., 2014), and has

142 been shown to enhance adhesion and invasion of Staphylococcus aureus (S. aureus) to bovine

143 mammary fibroblasts (Zao et al., 2017), which makes TGF $\beta$ an attractive target of future

144 research aimed to understand and control bovine mastitis. Further, with the strong evidence

145 supporting TGF $\beta 1$ 's effects on both the stromal and parenchymal compartments of the mammary

146 gland, a more holistic approach to studying TGF $\beta 1$ signalling incorporating both stromal and

147 epithelial cells may be necessary to study novel approaches to increasing milk production. In

148 vitro treatment of whole tissue explants (De Vries et al., 2011, Magro et al., 2017) is an attractive

149 possibility, as they may convey key mechanistic information impossible to obtain by analysis of

150 biopsies. Another alternative is the use of three-dimensional co-culture models that incorporate

151 ECM and stromal cells of interest in addition to the epithelial cells, as those recently developed

152 by our group (Pallegar et al., 2018). 

comprised of equal parts $\underline{T} G F \underline{\beta}$ receptors $\underline{I}$ (T $\beta R I)$ and $\underline{\text { II }}$ (T $\beta R I I)$. TGF $\beta 1$ ligands have high affinity for the type II but not type I TGF $\beta$ receptors (Massagué, 1998). Upon TGF $\beta 1$ ligand binding, the constitutively active T $\beta$ RII dimer binds and phosphorylates T $\beta$ RI, which becomes activated and phosphorylates receptor-associated small mothers against decapentaplegic (RSmad) transcription factors, specifically Smad2 and Smad3. These R-Smads form a complex with the co-Smad, Smad4, which translocates to the nucleus, where it associates with other transcriptional elements to regulate gene transcription (Figure 1). Among the factors affecting the outcome of canonical (Smad-mediated) TGF $\beta 1$ signalling are the type of R-Smad activated,

163 the nature of the interacting transcriptional co-activators and co-repressors, as well as the 164 phosphorylation site, whether at the carboxy terminus or the central linker region (Gilbert, 165 Vickaryous \& Viloria-Petit, 2016). In bovine mammary epithelial cells, TGF $\beta 1$ is documented to induce apoptosis and cell

167 growth arrest through canonical Smad signalling (Kolek et al., 2003). In non-bovine cells,

168 TGF $\beta 1$-induced apoptosis has also been reported to occur through non-canonical pathways such 169 as mitogen-activated protein kinase (MAPK)/Erk, p38, c-Jun N-Terminal Kinase, PI3K/Akt, and

170 Par6 signalling pathways (reviewed by Zhang 2009; Avery- Cooper et al., 2014). As mentioned

171 above, TGF $\beta 1$ has also been shown to inhibit mammary ductal branching in mice via Wnt

172 signalling activation (Roarty and Serra, 2007). Not all of these pathways have been explored in

173 bovine mammary epithelial cell apoptosis; however, downregulation of the PI3K/Akt and the

174 MAPK/Erk pathways occurs in parallel with TGF $\beta 1$-induced apoptosis and growth arrest of

175 bovine mammary epithelial cells in vitro (Gajewska and Motyl, 2004; Di et al., 2012). 
176 Contrary to its inhibitory effect on the bovine mammary epithelium, TGF $\beta 1$ promotes

177 stromal development in the mammary gland (Musters et al., 2004). TGF $\beta 1$ enhances bovine

178 fibroblast proliferation through the MAPK/Erk pathway (Gao et al., 2016), and promotes the

179 transition of fibroblasts to myofibroblasts (De Vries et al., 2011); the latter are key mediators of

180 ECM protein synthesis and tissue fibrosis (Phan, 2008). Furthermore, TGF $\beta 1$ is known to cause

181 bovine mammary epithelial cells to switch to a mesenchymal phenotype through a process

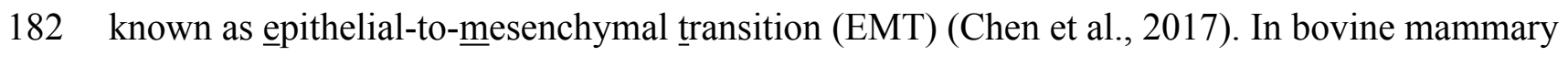

183 epithelial cells, EMT was reported to occur (at least in part) through the Smad pathway (Chen et

184 al., 2017). In non-bovine cells, other Smad-independent pathways have been implicated in TGF-

$185 \beta$-induced EMT such as the MAPK/Erk pathway, p38 MAPK, c-Jun N-terminal kinases, Par6

186 signaling and the PI3K/Akt pathway (Xu, Lamouille, \& Derynck, 2009; Avery Cooper et al.,

187 2014). A study exploring the use of tamoxifen as an inhibitor of tissue fibrosis, recently

188 demonstrated that TGF $\beta$ induces a mammary fibroblast to myofibroblast transition via activation

189 of MAPK/Erk signalling (Carthy et al., 2015). There is no current evidence on the involvement

190 of specific non-canonical signalling pathways in TGF $\beta 1$-induced EMT or fibroblast to

191 myofibroblasts conversion in bovine cells. Further research is necessary to understand the

192 contribution of non-canonical signalling pathways to TGF $\beta 1$-induced apoptosis, EMT, activation

193 of fibroblast into myofibroblasts, growth arrest, and mammogenesis in the bovine gland. 

assessed the effect of serum starvation on TGF $\beta 1$ synthesis and secretion. Zarzyńska, Gajewska

$197 \&$ Motyl (2005) mimicked the withdrawal of lactogenic hormones, growth factors, and nutrients

198 that occurs at the end of lactation and the beginning of involution by reducing fetal bovine serum

199 (FBS) content in the growth media from $10 \%$ to $0.5 \%$, and analyzed TGF $\beta 1$ expression

200 (Zarzyńska, Gajewska \& Motyl, 2005). In media containing 0.5\% FBS but not 10\% FBS, TGF $\beta 1$

201 protein and mRNA expression was increased (measured by laser scanning cytometry and RT-

202 PCR, respectively), and reached its maximum levels after 24 hours in BME-UV1 cells or 48

203 hours in MAC-T cells. These results suggested that a factor in FBS suppresses TGF $\beta 1$

204 expression. The authors demonstrated that IGF-I (a key player in the somatotropic axis mediated

205 by GH) suppresses TGFß1 expression in BME-UV1 cells and MAC-T cells (Zarzyńska,

206 Gajewska \& Motyl, 2005). The percentage of apoptotic cells was also measured (using the sub-

207 G1 region of a DNA histogram), and this reflected the patterns of TGF $\beta 1$ expression in MAC-T 208 and BME-UV1 cells (Zarzyńska, Gajewska \& Motyl, 2005). The investigators noted that there 209 was a positive relationship between endogenous TGF $\beta 1$ expression and apoptosis, which

210 provides support for the hypothesis that endogenous TGF $\beta 1$ induces apoptosis in these two cell 211 lines. BME-UV1 cells were also reported to undergo apoptosis and growth arrest in response to

212 exogenous ( $2 \mathrm{ng} / \mathrm{mL}) \mathrm{TGF} \beta 1$, and this was found to occur mainly through the intrinsic pathway

213 of apoptosis (Kolek et al., 2003). Gajewska, Gajkowska \& Motyl (2005) demonstrated the

214 formation of a Smad-DNA complex in the nucleus 2 hours after TGF $\beta 1$ treatment in BME-UV1

215 cells, indicating that the effects of TGF $\beta 1$ are transcriptionally mediated. 
In 1995, Woodward et al. studied the influence of TGF $\beta 1$ on cell proliferation and cell

217 death of MAC-T cells (Woodward et al., 1995). This study found that maximal reduction in

218 proliferation, as determined by total DNA measurements and thymidine incorporation, was

219 obtained at $40 \mathrm{pM}$ of TGF $\beta 1$. However, cytotoxicity (cell death) was not demonstrated by the

220 trypan blue exclusion method using a TGF $\beta 1$ concentration as high as $40 \mathrm{nM}$ (1000-fold greater

221 than $40 \mathrm{pM}$ ) (Woodward et al., 1995). This result contrasts the idea that TGF $\beta 1$ induces

222 apoptosis of MAC-T cells, suggested by the Zarzyńska, Gajewska \& Motyl (2005) study, which

223 found that maximum levels of apoptosis paralleled maximum levels of TGF $\beta 1$ ligand after 48

224 hours of serum starvation in MAC-T cells (Zarzyńska, Gajewska \& Motyl, 2005). Thus, the

225 evidence of TGF $\beta 1$-induced apoptosis of MAC-T cells is weak if not inexistent, compared to that

226 for BME-UV1 cells.

In addition to the studies discussed above with immortalized bovine MEC lines, an ex

vivo study on bovine mammary gland explants revealed increased caspase 3 and cleaved Parp in

parallel with increased levels of TGF $\beta 1$ and T $\beta$ R2 during the dry period (Zarzyńska et al., 2007).

These results provide indirect evidence that TGF $\beta 1$ induces apoptosis of bovine mammary

231 epithelial cells in vivo. Furthermore, the group of Di et al. (2012) demonstrated that exogenous TGF $\beta 1$ induces apoptosis of primary bovine mammary epithelial cells isolated from the bovine mammary gland. This study revealed that levels of the death receptor ligand Fas ligand (FasL) were reduced in parallel with increased levels of TGF $\beta 1$-induced apoptosis, which supports the findings by Kolek et al. (2003) demonstrating that TGF $\beta 1$-induced apoptosis in bovine mammary epithelial cells occurs through the intrinsic mitochondrial pathway. The results of this

237 ex vivo assay demonstrate that primary bovine mammary epithelial cells undergo TGF $\beta 1$ -

238 induced apoptosis, similar to the BME-UV1 cells (Kolek et al., 2003), and this provides strong 
239 support for the idea that BME-UV1 mimic the behavior of cells directly isolated from the bovine

240 mammary gland. 
243 involved in the apoptotic response to TGF $\beta 1$ in BME-UV1 cells. In these cells, TGF $\beta 1$ was

244 found to increase the expression of insulin-like growth factor binding protein (IGFBP)-3 and

245 IGFBP-4, which led to the sequestration of IGF-I from the IGF-I receptor, reduction of PI3K/Akt

246 signalling, and increased expression of the pro-apoptotic protein $\underline{B} c 1-2$-associated death promoter

247 (Bad) (Gajewska and Motyl, 2004). A separate study found that exogenous IGF-I administration

248 to BME-UV1 cells completely blocked TGF $\beta 1$ expression and apoptosis, and this effect was

249 reversed through the use of a PI3K inhibitor (Zarzyńska and Motyl, 2005). In agreement with the

250 studies performed on BME-UV1 cells, Di et al. (2012) demonstrated that increased levels of Bad

251 mediated the apoptotic response to TGF $\beta 1$ in primary non-immortalized bovine mammary

252 epithelial cells isolated from the bovine mammary gland, which lends support to the hypothesis

253 that TGF $\beta 1$-induced apoptosis in bovine mammary epithelial cells is mediated in part by a

254 reduction of PI3K/Akt signalling. Altogether, this provides additional support for the argument

255 that BME-UV1 cells closely resemble the responses to TGF $\beta 1$ that are seen in primary bovine

256 mammary epithelial cells.

257

Zarzyńska, Gajewska \& Motyl (2005) compared the effects of GH and somatostatin (a

negative regulator of $\mathrm{GH}$ ) on TGF $\beta 1$ expression in MAC-T and BME-UV1 cells (Table 1). GH

significantly reduced TGF $\beta 1$ levels in BME-UV1 cells supplemented with $10 \%$ FBS (nutrient-

260 rich conditions), while it significantly increased TGF $\beta 1$ levels in BME-UV1 cells supplemented

261 with $0.5 \%$ FBS (nutrient-poor conditions). Treatment with somatostatin, a negative regulator of

262 GH, was only evaluated in BME-UV1 cells supplemented with 10\% FBS, in which it increased

263 TGF $\beta 1$ protein levels. This suggests that in nutrient-rich conditions such as those expected 
264 during lactation, GH suppresses TGF $\beta 1$ expression in the bovine mammary gland, an effect that

265 is blocked by somatostatin. In MAC-T cells, GH and somatostatin did not affect TGF $\beta 1$ protein

266 levels (Zarzyńska, Gajewska \& Motyl, 2005). Thus, TGF $\beta 1$ expression is altered by hormones of

267 the somatotropic axis such as GH and somatostatin in BME-UV1 cells, but not in MAC-T cells

268 (Zarzyńska, Gajewska \& Motyl, 2005). Taken together with the demonstrated role of the

269 somatotropic axis in the control of survival in bovine mammary epithelial cells (Gajewska and

270 Motyl, 2004), the results discussed above suggest that the modulation of TGF $\beta 1$ levels and

271 subsequent activity by the somatotropic axis is a mechanism to control survival/apoptosis in

272 BME-UV1 cells but not in MAC-T cells.

273 The above results are also supported by in vivo evidence. Zarzyńska et al. (2007)

274 evaluated the expression of TGF $\beta 1$, TGF $\beta$ RII, IGF-I Receptor $\alpha$ (IGF-IR $\alpha$ ), IGF-I Receptor $\beta$

275 (IGF-IR $\beta$ ), GH-R, IGFBP-3, -4, and -5, as well as biochemical markers of apoptosis (cleaved

276 Parp and caspase 3) in bovine mammary gland explants at early lactation, late lactation, and

277 during dry off (Zarzyńska et al., 2007). This study revealed that increased apoptosis, TGFß1,

278 TGFRRII, IGFBP-4, and-5 expression was accompanied by downregulation of GH-R and IGF-

279 IR $\alpha$ during dry off (Zarzyńska et al., 2007). This suggests that TGFß1 exerts its pro-apoptotic

280 effects through suppression of the somatotropic pathway (Figure 2).

281 As discussed above, IGF-I somatogenic effects have been shown to be caused, at least in

282 part, by inhibition of TGF $\beta 1$ signalling (Zarzyńska and Motyl, 2005). Thus, IGF-I administration

283 might be an effective way to block TGF $\beta 1$ signalling and its pro-apoptogenic and

284 antiproliferative effects in vivo; in fact, this has already been done in an in vitro study by

285 Zarzyńska and Motyl (2005). In vivo studies examining the effect of IGF-I on milk production

286 have yielded inconsistent results. Davis et al. (1989) compared the effects of administering 
287 systemic infusions of IGF-I or GH to lactating goats and measured the effects on milk production

288 over a 10-day period. After 36 hours, goats receiving GH had a milk yield increased by an

289 average of $24 \%$, while goats receiving IGF-I had no significant increase in milk yield compared

290 to saline-infused goats (Davis et al., 1989). In agreement with these results, intramammary

291 infusion of IGF-I had no significant effect on milk protein expression or milk yield in dairy cows

292 after a 4-day treatment interval (Mackle et al., 2000). Conversely, infusion of IGF-I for 6 hours

293 via an external pudic arterial catheter in lactating goats resulted in milk yield significantly

294 increased by $9 \% 2$ hours post-infusion, and this was associated with significantly increased

295 mammary blood flow by $50-80 \%$ (Prosser et al., 1994).

296 Taken together, the above evidence does not consistently support an impact of IGF-I

297 administration (and possibly indirect TGF $\beta 1$ inhibition) on acute milk yield following IGF-I

298 administration. One limitation of these studies is that only short periods of time were used to

299 examine milk production, rather than measuring the amount of milk produced over the entire

300 lactation period, which has an average length of 225 days in goats and 305 days in cattle (Ahuya

301 et al., 2009; Bachman \& Schairer, 2003). It is possible that IGF-I administration could delay the

302 onset of apoptosis and growth arrest that occurs in secretory epithelial cells leading to the decline

303 in lactation and the beginning of involution without increasing peak milk yield. We propose that

304 exogenous administration of IGF-I would extend the time in which peak yield is maintained

305 compared to control cows. This area of research has not been recently investigated and many

306 unknown questions still remain regarding harnessing TGF $\beta 1$ signalling for the purposes of

307 extending lactation. For instance, many studies have focused on TGF $\beta 1$ 's effect on cell number,

308 but have not evaluated TGF $\beta 1$ 's possible effect of metabolic activities of secretory epithelial

309 cells during lactation. 
In the previous section, we provided evidence of TGF $\beta 1$-induced apoptosis in BME-

312 UV1, but not MAC-T cells (Kolek et al., 2003; Woodward et al., 1995), and we also discussed

313 how the somatotropic axis controls TGF $\beta 1$ expression in the former but not the latter (Zarzyńska,

314 Gajewska \& Motyl, 2005). Comparing the literature on MAC-T and BME-UV1 cells yielded

315 some very important differences that should be taken into account before using these cell lines to 316 study TGF $\beta 1$ signalling.

317 The cell populations that compose the MAC-T and BME-UV1 cell lines were previously

318 identified via determination of cell surface marker and cytokeratin expression under standard

319 adherent (ADH), uㅣtra-low adherence (ULA) and three-dimensional (3D) laminin-rich

320 (Matrigel $^{\mathrm{TM}}$ ) culture conditions (Arévalo Turrubiarte et al., 2016). Staining of the luminal-

321 specific cytokeratin (CK) CK19 and myoepithelial-specific CK14 (both human-specific

322 antibodies) (Borena et al., 2013) was used to identify luminal and myoepithelial cell populations,

323 respectively. Staining of CK19 and CK14 was supplemented by evaluating epithelial cell

324 adhesion molecule (EpCAM) expression using a mouse-specific antibody. EPCAM is a cell-

325 surface marker more highly expressed in bovine luminal-alveolar progenitor cells compared to

326 other mammary epithelial cell types (Perruchot et al., 2016). To further support the luminal cell

327 classification, Arévalo Turrubiarte et al. (2016) examined aldehyde dehydrogenase (ALDH)

328 activity under standard adherence conditions, as ALDH is highly expressed in bovine luminal

329 progenitor cells compared to other bovine mammary epithelial cell populations (Martignani et

330 al., 2010).

331 In order to assess basal phenotype, Arévalo Turrubiarte et al. assessed cluster of

332 differentiation (CD) markers: CD49f (integrin $\alpha 6$ chain) using a rat-specific antibody and CD10 
333 (neutral endopeptidase) using a mouse-specific antibody. CD49f is responsible for cell-matrix

334 adhesions and for transmitting signals between mammary epithelial cells and the ECM (Giancotti

335 and Ruoslahti, 1999). CD49f is expressed in cells of both luminal and basal origin; however, it is

336 more highly expressed in basal cells (Finot, Chanat \& Dessauge, 2018; Rauner and Barash,

337 2012; Perruchot et al., 2016). CD10, on the other hand, is normally used as a marker of basal

338 cells (Safayi et al., 2012), but it is also enriched in mammosphere-forming cell populations;

339 hence CD10 is also used as a marker of stem cells (Maguer-Satta, Besançon \& Bachelard-

340 Cascales, 2011). The ambiguity surrounding the significance of CD10 staining is addressed by

341 staining for multiple markers in order to not misidentify cell phenotypes. For example, an

342 additional marker of basal cells that can be used is CK14 (Borena et al. 2013), which was also

343 included in the panel by the aforementioned researchers (Arévalo Turrubiarte et al., 2016).

344 Arévalo Turrubiarte et al. (2016) marker expression assessment in BME-UV1 cells led to the

345 conclusion that they have a luminal phenotype based on their high expression of EpCAM and

346 CK19, and their high ALDH activity. Interestingly, the BME-UV1 cells also express CD10. In

347 the absence of any other basal markers, these investigators interpreted the high CD10 expression

348 and high ALDH activity of BME-UV1 cells as having a greater "stem-like" phenotype compared

349 to the MAC-T cells (Arévalo Turrubiarte et al., 2016; Table 2).

350 The MAC-T cells were found by the same investigators to have a higher CD49f

351 expression and lower ALDH activity compared to the BME-UV1 cells under standard adhesion

352 culture conditions. In addition, MAC-T cells expressed CK14, a cytokeratin characteristic of

353 myoepithelial cells, while the BME-UV1 cells did not (Arévalo Turrubiarte et al., 2016). The

354 high expression of CD49f, the low ALDH activity, and the expression of CK14 suggest that

355 MAC-T cells contain a myoepithelial cell population (Arévalo Turrubiarte et al., 2016; Table 2). 
356 Although the MAC-T cells contain characteristics indicative of myoepithelial cells, these cells

357 were previously reported to lack oxytocin responsiveness and smooth muscle actin expression

358 (Zavizion, Gorewit \& Politis, 1995), which are two hallmarks of myoepithelial cells (Gudjonsson

359 et al., 2005). Further, Arévalo Turrubiarte et al (2016) found MAC-T cells to lack CD10, which

360 is a marker also expressed by mature bovine myoepithelial cells (Perruchot et al., 2016). It is

361 important to note that the assessment of oxytocin and smooth muscle actin in MAC-T was

362 performed following their culture as monolayers on glass (Zavizion, Gorewit \& Politis, 1995).

363 Instead, a 3D culture model on reconstituted basement membrane, such as Matrigel ${ }^{\mathrm{TM}}$, could be

364 employed in order to examine the myoepithelial potential of the MAC-T cells. We based this

365 suggestion in studies by Mroue et al. (2015), in which a role for the gap junction protein

366 Connexin 43 was demonstrated in the contractile response of myoepithelial cells to oxytocin via

367 assessment of mouse derived mammary epithelial cell organoids under 3D culture conditions on

368 Matrigel $^{\mathrm{TM}}$. Appropriate ECM interactions under these conditions might promote differentiation

369 into a myoepithelial phenotype capable of proper assembly of functional gap junctions and

370 consequently contractibility following oxytocin exposure. Another thing to note about the study

371 by Arévalo Turrubiarte et al. (2016) is the use of non-bovine specific antibodies (human-specific

372 CK14 and CK19, rat-specific EpCAM, and mouse-specific CD49f and CD10), which does not

373 take into account interspecies differences. To illustrate this concern, the UniProt Consortium

374 (2017) revealed that human and bovine CK14 and CK19 have $91.1 \%$ and $88.8 \%$ protein

375 sequence homology, respectively, while rat and bovine EpCAM and CD49f share $78.1 \%$ and

376 91.9\% protein homology, respectively. Lastly, mouse and bovine CD10 share $91.3 \%$ protein

377 homology (The UniProt Consortium, 2017). These differences in protein sequences between 
378 bovine, and the species against which the antibody was directed, can lead to misleading results

379 not necessarily reflecting the true levels of expression or a given protein.

380 Another interesting feature of the MAC-T cells is their capability of synthetizing $\alpha$ - and

$381 \beta$-casein, which is indicative that there are luminal/alveolar cells present within this cell line

382 (Huynh, Robitaille \& Turner, 1991). One explanation to the bi-phenotypic features of MAC-T

383 cells, is that they contain bi-potent progenitor cells that gave rise to cells of both basal and

384 luminal origin (Rauner and Barash, 2012). One study, which investigated the ability of MAC-T

385 cells to form a functional mammary gland in vivo, suggests that this might be the case. MAC-T

386 cells were mixed with the reconstituted ECM Matrigel ${ }^{\mathrm{TM}}$, and were implanted into the dorsal

387 tissue of 8-week-old BALB/C nude male mice (Park et al., 2016). After 6 weeks, the

388 transplanted tissue of these mice was dissected and analyzed for bovine mammary protein

389 expression (Park et al., 2016). At this time, the MAC-T transplants had the characteristic alveolar

390 structures of a female mammary gland (Park et al., 2016). These investigators evaluated the

391 expression of CK18 and CK14 (luminal and myoepithelial cytokeratins, respectively), both in the

392 mammary tissue sections, as well as in vitro. The tissue sections expressed CK18, mainly

393 localized in the luminal cells, and CK14, which was mainly localized in the ductal and

394 myoepithelial cells. The MAC-T cell line grown in monolayer culture stained positively for both

395 CK14 and CK18 (Park et al., 2016). These results suggest that the MAC-T cell line contains a

396 heterogeneous population. The above findings are additionally supported by a previous study in

397 which MAC-T cells were subcloned into three distinct cell lines (Zavizion, Gorewit \& Politis, 398 1995).

399 Both MAC-T and BME-UV1 cells are derived from lactating mammary epithelium, 400 however there were differences in the generation of these cell lines that should be considered. 
401 Although both cell lines were immortalized via transfection with simian virus 40 (SV40) large T

402 antigen (the temperature sensitive tsA58 mutant T antigen, specifically) and they were generated

403 from mammary tissue obtained at slaughter from Holstein cows; BME-UV1 were obtained from

404 a pregnant lactating cow (Zavizion et al., 1996), while MAC-T cells were obtained from a non-

405 pregnant lactating cow (Huynh, Robitaille \& Turner, 1991). Further, the transfection to generate

406 BME-UV1 cells was carried out on a homogenous population of cells generated by subcloning a

407 luminal-enriched cell population (Zavizion et al., 1996), while the transfection to generate MAC-

408 T cells was performed on cells of epithelial morphology derived from serial dilution cloning of

409 the original heterogeneous population of mammary cells (Huynh, Robitaille \& Turner, 1991).

410 Thus, differences between the MAC-T and BME-UV1 cells may be a consequence of the

411 differing physiological statuses of the animals that were sampled and/or the cell population that

412 was immortalized. It is also possible that the cells acquired different phenotypes due to lab-

413 specific culture conditions since different culture conditions were used to generate the cells

414 (Arévalo Turrubiarte et al., 2016). Such effect of culture conditions on the phenotype acquired

415 by mammary epithelial cells has indeed been reported for human mammary cells (Ince et al.,

416 2007). 

their maximum in parallel with apoptosis. Apart from this study, there is no other evidence kinase inhibitors and/or TGF $\beta 1$ blocking antibodies, in order to conclusively demonstrate that apoptosis of MAC-T cells under starving conditions in induced by TGF $\beta 1$. Suppression of $\mathrm{PI} 3 \mathrm{~K} /$ Akt activity was reported to mediate TGF $\beta 1$-induced apoptosis of BME-UV1 cells

MAC-T cells has never been explored. Individual and combination treatments of exogenous

TGF $\beta 1$, a T $\beta$ RI/II kinase inhibitor, and a PI3K/Akt inhibitor would reveal the contribution of the PI3K/Akt pathway to the antiproliferative and apoptogenic effect of TGF $\beta 1$ in MAC-T cells. From the available ex vivo studies demonstrating TGF $\beta 1$-induced apoptosis in primary bovine mammary epithelial cells (Di et al., 2012; Zarzyńska et al., 2007) and the similar capacity of

431 BME-UV1 cells to undergo apoptosis in response to TGF $\beta$ (Kolek et al., 2003), we can infer that BME-UV1 cells resemble the in vivo bovine mammary epithelium in relation to apoptosis. population based on the presence of both luminal and basal phenotypes (Arévalo Turrubiarte et al., 2016; Park et al., 2016). It would first be necessary to prove this by performing a clonal assay on MAC-T cells to demonstrate these cells give rise to both luminal and basal cells. A

437 further step would be to compare the effect of TGF $\beta 1$ on MAC-T cells to that on bi-potent 438 progenitors derived from bovine mammary explants, in order to evaluate if cell line 439 immortalization is a confounding variable. In recent years, several different models of epithelial 
440 cell hierarchy in the bovine mammary gland have been proposed (Rauner and Barash, 2012;

441 Perruchot et al., 2016; Finot, Chanat \& Dessauge, 2018). A better understanding of lineage

442 commitment to basal or luminal phenotypes may shed light on the different origins of MAC-T

443 and BME-UV1 cells, and thus guide their appropriate use in studies aimed to elucidate the role

444 of TGF $\beta$ in bovine mammary epithelium apoptosis and bovine mammary gland biology in

445 general.

In relation to the inverse relationship between the somatotropic and the TGF $\beta$ signalling

447 pathway, studies in the past have found that IGF-I administration to dairy animals resulted in no change in milk production (Davis et al. 1984; Mackle et al, 2000). We suggest that these results

449 may reflect the study design. When evaluating the efficacy of a treatment, it is important that we address lactation persistency in terms of peak milk production as well as what happens before and after, by measuring milk production over the entire lactation period. IGF-I may not necessarily increase peak milk production in dairy cows, but it may still reduce the decline in milk production that inevitably follows peak milk yield. Another approach to reducing TGF $\beta 1$ 's potent apoptogenic and anti-proliferative effects on the epithelium and stimulatory effects on the stroma is to modify the dairy cow's diet. For example, Gao et al. (2016) demonstrated that dairy cows fed a diet of corn stover had higher serum levels of TGF $\beta 1$ compared to cows fed a diet of alfalfa. Furthermore, mammary glands of cows fed the diets of corn stover and alfalfa were examined ex vivo, and the former demonstrated increased levels of TGF $\beta 1$ and increased levels of vimentin (a marker of mammary stroma). This suggests that we can indirectly affect TGF $\beta 1$

460 signalling through modifying nutrition of dairy cows. This may be the most cost-efficient and

461 practical approach to modifying TGF $\beta 1$ signalling in order to increase milk production, rather

462 than the administration of growth factors or hormones such as IGF-I and rBST, respectively. 
An important concern to note is that inhibition of TGF $\beta 1$ signalling can result in

464 undesired side effects such as delayed wound healing and chronic inflammation (Herbertz et al.

465 2015). Furthermore, TGF $\beta 1$ plays an important role in mammary gland remodeling during

466 involution since it is likely responsible for, at least in part, replacing senescent secretory

467 epithelial cells (Di et al., 2012; Zarzyńska et al., 2007), and for promoting stromal development

468 (Musters et al., 2004). Therefore, inhibiting TGF $\beta 1$ completely to prevent involution and the dry

469 period would not be well-advised. In fact, De Vries et al. (2011) suggested that, rather than

470 inhibiting TGF $\beta \square \square \square \square \square \square \square \square \square$, exogenous TGF $\beta 1$ could be used during the first week of

471 the dry period to hasten remodeling, shorten the dry period, and thus maximize milk production

472 in the subsequent lactation period. It would be interesting to test this hypothesis in vivo by

473 administering TGF $\beta 1$ during early dry period and comparing the effects to inhibition of TGF $\beta 1$

474 during the same time window, or comparing the same contrasting approaches during the late dry

475 period. The length of the treatment is an important factor to take into consideration when

476 designing these experiments, given the potential enhancement of mastitis susceptibility by

477 TGF $\beta$. A shorter treatment time might be required, based on the above-discussed evidence that

478 TGF $\beta 1$ enhances $S$. aureus adhesion and invasion into bovine mammary fibroblasts (Zhao et al.,

479 2017). Taking this into account, any studies administering TGF $\beta 1$ in dairy cows should report

480 prevalence of mastitis in different treatment groups to ensure that TGF $\beta 1$ is not predisposing

481 dairy cows to intramammary infections.

482 Most researchers studying involution and lactation focus on the mammary epithelium, but

483 recent work has demonstrated that TGF $\beta 1$ equally affects the mammary stroma. Future research

484 is necessary to understand how TGF $\beta 1$ 's effect on the stroma affects the epithelial compartment.

485 This would be particularly useful in determining if stromal-epithelial interactions affect how 
486 closely MAC-T and BME-UV1 cells match the response of in vivo bovine mammary epithelial 487 cells to TGF $\beta 1$. We can evaluate the effect of epithelial-stromal interactions on TGF $\beta 1$ 488 signalling by employing bovine mammary gland explants (De Vries et al., 2011, Magro et al., 489 2017), or a 3D culture system with re-constituted ECM (such as Matrigel ${ }^{\mathrm{TM}}$ ) to more accurately 490 mimic the in vivo mammary gland (Lee et al., 2007). Another option is to use a co-culture system 491 containing stromal cells (fibroblasts, adipocytes, or both) in addition to the epithelial cells 492 (Zhang et al., 2002) or in addition to the epithelial cells and the ECM (Pallegar et al., 2018).

493 Taking this approach will allow scientists to gain a better understanding of the interaction 494 between epithelial and stromal compartments, and how this affects cell behavior. 
497 involution, and can potentially be manipulated in order to increase lactation persistency. In the 498 bovine mammary gland, MAC-T and BME-UV1 cell lines have different responses to TGF $\beta 1$, 499 and these responses should be carefully considered before employing them to study TGF $\beta 1$

500 signalling. BME-UV1 cells have been documented to undergo apoptosis in response to 501 exogenous and endogenous TGF $\beta 1$, and this involved suppression of the somatotropic pathway

502 (Kolek et al., 2003; Zarzyńska, Gajewska \& Motyl, 2005; Gajewska and Motyl, 2004).

503 Conversely, TGF $\beta 1$-induced apoptosis of MAC-T cells has never been demonstrated, and no 504 involvement of the GH/IGF-I/PI3K/Akt pathway has been reported. Furthermore, hormones of 505 the somatotropic pathway (GH and somatostatin) alter TGF $\beta 1$ expression in BME-UV1, but not 506 in MAC-T cells (Zarzyńska, Gajewska \& Motyl, 2005).

507 The different responses of BME-UV1 and MAC-T cells to TGF $\beta 1$ is possibly a result of 508 their differing phenotypes. BME-UV1 cells express a luminal phenotype, while MAC-T cells 509 possess a phenotype indicative of both luminal and myoepithelial populations (Arévalo

510 Turrubiarte et al., 2016). For researchers wishing to study interactions between TGF $\beta 1$ signalling

511 and the somatotropic pathway in alveolar bovine mammary epithelial cells, the current evidence

512 suggests that BME-UV1 cells better reflect the physiology of milk-secreting bovine alveolar 513 mammary epithelial cells.

514 Taking into account TGF $\beta 1$ 's effect on mammary stroma and the role of stromal-

515 epithelial interactions in mammary gland physiology, the influence of stromal cells is an 516 important factor to consider when testing how closely bovine mammary cell lines (including 
517 MAC-T and BME-UV1) resemble the in vivo mammary gland. The experimental design for

518 future research involving MAC-T and BME-UV1 cells should keep this in mind.

520 We would like to recognize all the support and suggestions we received from members of

521 the Viloria-Petit, Coomber, and Mutsaer laboratories, as well as from a number of other

522 members of the Department of Biomedical Sciences at the University of Guelph. Our special

523 thanks to Charles Mitz and Mary Ellen Cybulski for their critical review of the manuscript. We

524 dedicate this work to the memory of C.A.M. grandfather, Larry Mitz. 
526

527

528

529

530

531

532

533

534

535

536

537

538

539

540

541

542

543

544

545

546

547

548

549

550

551

552

553

554

555

556

557

558

559

Ahuya C, Ojango J, Mosi R, Peacock C, Okeyo A. Performance of Toggenburg dairy goats in smallholder production systems of the eastern highlands of Kenya. Small Ruminant Research 83: 7-13 DOI: 10.1016/j.smallrumres.2008.11.012.

Arévalo Turrubiarte M, Perruchot M, Finot L, Mayeur F, Dessauge F. 2016. Phenotypic and functional characterization of two bovine mammary epithelial cell lines in 2D and 3D models. American Journal of Physiology - Cell Physiology 310:C348-C356 DOI: 10.1152/ajpcell.00261.2015.

Andreotti C, Pereyra E, Baravalle C, Renna M, Ortega H, Calvinho L, Dallard B. 2014. Staphylococcus aureus chronic intramammary infection modifies protein expression of transforming growth factor beta (TGF- $\beta$ ) subfamily components during active involution. Research in Veterinary Science 96:5-14 DOI: 10.1016/j.rvsc.2013.11.002.

Argetsinger L, Campbell G, Yang X, Witthuhn B, Silvennoinen O, Ihle J. Carter-Su C. 1993. Identification of JAK2 as a growth hormone receptor-associated tyrosine kinase Cell 74:237-244 DOI: 10.1016/0092-8674(93)90415-M.

Avery-Cooper G, Doerr M. Gilbert R, Youssef M, Richard A, Huether P, Viloria-Petit A. 2014. Par6 is an essential mediator of apoptotic response to transforming growth factor beta in NMuMG immortalized mammary cells. Cancer Cell International 14:19 DOI: 10.1186/14752867-14-19.

Bachman K, Schairer M. 2003. Invited review: bovine studies on optimal lengths of dry Periods. Journal of Dairy Sciences 86:3027-3037 DOI:10.3168/jds.S0022-0302(03)73902-2

Bauman D. 1999. Bovine somatotropin and lactation: from basic science to commercial application. Domestic Animal Endocrinology 17:101-116 DOI: 10.1016/S0739-7240(99)000284.

Borena B, Bussche L, Burvenich C, Duchateau L, Van de Walle G. 2013. Mammary stem cell research in veterinary science: An Update. Stem Cells and Development 22:1743-1751 DOI: 10.1089/scd.2012.0677.

Bruckmaier R, Blum J. 1998. Oxytocin release and milk removal in ruminants. Journal of Dairy Science 81(4):939-949 DOI:10.3168/jds.S0022-0302(98)75654-1.

Capuco A, Ellis S, Hale S, Long E, Erdman R, Zhao X, Paape M. 2003. Lactation persistency: insights from mammary cell proliferation studies. Journal of Animal Science 81:18-31 DOI: 10.2527/2003.81suppl_318x.

Carthy J, Sunqvist A, Heldin A, van Dam H, Kletsas D, Heldin C, Moustakas A. 2015. Tamoxifen inhibits TGF- $\beta$-mediated activation of myofibroblasts by blocking non-Smad 
560 signaling through ERK1/2. Journal of Cellular Physiology 230:3084-92 DOI:

$561 \quad 10.1002 /$ jcp. 25049.

562

563 Chen Q, Yang W, Wang X, Li X, Qi S, Zhang Y, Gao M. 2017. TGF- $\beta 1$ Induces EMT in Bovine

564 Mammary Epithelial Cells Through the TGF $\beta 1 /$ Smad Signaling Pathway. Cellular Physiology

565 and Biochemistry 43:82-93 DOI: 10.1159/000480321.

566 Collier R, Annen-Dawson E, Pezeshki A. 2012. Effects of continuous lactation and short dry

567 periods on mammary function and animal health. Animal 6:403-414

568 DOI:10.1017/S1751731111002461

569

570

571

572

573

574

575

576

577

578

579

580

Davis S, Gluckman P, Hodgkinson S, Farr V, Breier B, Burleigh B. 1989. Comparison of the Effects of Administration of Recombinant Bovine Growth Hormone or N-Met Insulin- like Growth Factor-I to Lactating Goats. Journal of Endocrinology. 123:33-39.

De Vries L, Casey T, Dover H, VandeHaar M, Plaut K. 2011. Effects of transforming growth factor- $\beta$ on mammary remodeling during the dry period of dairy cows. Journal of Dairy Science 94:6036-6046 DOI: 10.3168/jds.2011-4590.

De Vries L, Dover H, Casey T, VandeHaar M, Plaut K. 2010. Characterization of mammary stromal remodeling during the dry period. Journal of Dairy Science 93:2433-2443 DOI: $10.3168 /$ jds.2009-2764.

Di H, Wang L, Wang G, Zhou L, Yang Y. 2012. The signaling mechanism of TGF- $\beta 1$ induced bovine mammary epithelial cell apoptosis. Asian-Australasian Journal of Animal Sciences

581 25:304-310 DOI: 10.5713/ajas.2011.11251.

582 Dohoo I, DesCôteaux L, Leslie K, Fredeen A, Shewfelt W, Preston A, Dowling P. 2003. A meta583 analysis review of the effects of recombinant bovine somatotropin. Canadian Journal of 584 Veterinary Research 67 252-264 PMID: 1462861.

585 Etherton T, Bauman D. 1998. Biology of somatotropin in growth and lactation of domestic 586

587 Finot L, Chanat E, Dessauge F. 2018. Bovine mammary gland development: new insights into 588 the epithelial hierarchy. bioRxiv 251637 [Preprint] DOI: 10.1101/251637.

Forge, Frédéric. 1998. RECOMBINANT BOVINE SOMATOTROPIN (rbST). Library of Parliament - Parliamentary Research and Information Service. Available at: https://lop.parl.ca/Content/LOP/ResearchPublicationsArchive/bp1000/prb981-e.asp (accessed May 14, 2018).

Fornetti J, Flanders K, Henson P, Tan A-C, Borges V, Schedin P. 2016. Mammary epithelial cell phagocytosis downstream of TGF- $\beta 3$ is characterized by adherens junction reorganization. Cell Death and Differentiation 23:185-196 DOI:10.1038/cdd.2015.82. 
589 Gajewska M, Gajkowska B, Motyl T. 2005. Apoptosis and autophagy induced by TGF- $\beta 1$ in

590 bovine mammary epithelial BME-UV1 cells. Journal of Physiology and Pharmacology 56:143-

591157.

592 Gajewska M, Motyl T. 2004. IGF-binding proteins mediate TGF-beta 1-induced apoptosis in 593 bovine mammary epithelial BME-UV1 cells. Comparative Biochemistry and Physiology Part C:

594 Toxicology \& Pharmacology 139:65-75 DOI: 10.1016/j.cca.2004.09.006.

595 Gao Y, Wang Y, Li Y, Xia X, Zhao S, Che Y, Sun Y, Lei L. 2016. TGF- $\beta 1$ promotes bovine 596 mammary fibroblast proliferation through the ERK 1/2 signalling pathway. Cell Biology

597 International 40: 750-760 DOI: 10.1002/cbin.

598 Giancotti F, Ruoslahti E. 1999. Integrin signalling. Science 285:1028-1032 DOI:

599 10.1126/science.285.5430.1028

600 Gilbert R, Vickaryous M, Viloria-Petit A. 2016. Signalling by transforming growth factor beta 601 isoforms in wound healing and tissue regeneration. Journal of Developmental Biology 4:21 DOI: $60210.3390 / j \mathrm{db} 4020021$.

603 Grossman M, Hartz S, Koops W. 1999. Persistency of lactation yield: a novel approach. Journal 604 of Dairy Science 82: 2192-2197 DOI: 10.3168/jds.S0022-0302(99)75464-0.

605 Gudjonsson T, Adriance M, Sternlicht M, Petersen O, Bissell M. 2005. Myoepithelial cells: their 606 origin and function in breast morphogenesis and neoplasia. Journal of Mammary Gland Biology 607 and Neoplasia 10: 261-272 DOI: 10.1007/s10911-005-9586-4.

608 Heikkilä A, Nousiainen J, Pyörälä S. 2012. Costs of clinical mastitis with special reference to 609 premature culling. Journal of Dairy Science 95:139 -150 DOI: 10.3168/jds.2011-4321.

610 Holst B, Hurley W, Nelson D. 1987. Involution of the bovine mammary gland: histological and 611 ultrastructural changes. Journal of Dairy Science 70:935-944 DOI: 10.3168/jds.S0022-

612 0302(87)80097-8.

613 Herbertz S, Sawyer J, Stauber A, Gueorguieva I, Driscoll K, Estrem S, Cleverly A, Desaiah D, 614 Guba S, Benhadji K, Slapak C, Lahn M. 2017. Clinical development of galunisertib (LY2157299 615 monohydrate), a small molecule inhibitor of transforming growth factor-beta signaling pathway.

616 Drug Design, Development and Therapy 9:4479-99 DOI: 10.2147/DDDT.S86621.

617

618 Hurley W, Loor J. 2011. Mammary gland | growth, development and involution. In: Fuquay JW, 619 ed. Encyclopedia of Dairy Sciences. San Diego: Academic Press. 338-345 DOI: 10.1016/B978620 0-08-100596-5.21408-X.

621 Hurley W. 1989. Mammary gland function during involution. Journal of Dairy Science 72:1637622 1646 DOI: $10.3168 /$ jds.S0022-0302(89)79276-6.

623 Huynh H, Robitaille G, Turner J. 1991. Establishment of bovine mammary epithelial cells 
624 (MAC-T): An in vitro model for bovine lactation. Experimental Cell Research 197:191-199

625 DOI: 10.1016/0014-4827(91)90422-Q.

626 Ince T, Richardson A, Bell G, Saitoh M, Godar S, Kamoub A, Iglehart J, Weinberg R. 2007.

627 Transformation of different human breast epithelial cell types leads to different tumor

628 phenotypes. Cancer Cell 12:160-170 DOI: 10.1016/j.ccr.2007.06.013.

629 Jedrzejczak M, Szatkowska I. 2014. Bovine mammary epithelial cell cultures for the study of 630 mammary gland functions. In Vitro Cellular \& Developmental Biology - Animal 50:389-398

631 DOI: $10.1007 / \mathrm{s} 11626-013-9711-4$.

632 Kass L, Erler J, Dembo M, Weaver V. 2007. Mammary epithelial cell: influence of extracellular 633 matrix composition and organization during development and tumorigenesis. The International

634 Journal of Biochemistry \& Cell Biology 30:1987-1994 DOI: 10.1016/j.biocel.2007.06.025.

635 Kolek O, Gajkowska B, Godlewski M, Motyl T. 2003. Antiproliferative and apoptotic effect of

636 TGF- $\beta 1$ in bovine mammary epithelial BME-UV1 cells. Comparative Biochemistry and

637 Physiology Part C: Toxicology \& Pharmacology 134:417-430 DOI: 10.1016/S1532-

638 0456(02)00249-1.

639 Lasky J, Brody A. 2000. Interstitial fibrosis and growth factors. Environmental Health

640 Perspectives 108:751-762 DOI: 10.1289/ehp.00108s4751.

641 Lee G, Kenny P, Lee E, Bissell M. 2007. Three-dimensional culture models of normal and

642 malignant breast epithelial cells. Nature Methods 4: 359-365 DOI: 10.1038/nmeth1015.

643 Mackle T, Dwyer D, Bauman D. 2000. Intramammary infusion of insulin or long R3 insulin-like 644 growth factor-I did not increase milk protein yield in dairy cows. Journal of Dairy Science

645 83:1740-1749 DOI: 10.3168/jds.S0022-0302(00)75044-2.

646 MacLeod S, Gougeon R, Marks G, Pollak M, Tenenbein M, Woodland C. 1999. Report of the

647 Royal College of Physicians and Surgeons of Canada Expert Panel on Human safety of RBST.

648 Ottawa (ON): Health Canada. Available at: https://www.canada.ca/en/health-

649 canada/services/drugs-health-products/veterinary- drugs/other-issues/recombinant-bovine-

650 somatotropin-rbst/executive-summary-report- royal-college-physicians-surge)ns-canada-expert-

651 panel-human-safety-rbst-health- canada-1999.html (accessed 2017 Dec 7).

652

653 Magro G, Brevini TAL, De Maglie M, Minozzi G, Scanziani E, Piccinini R. 2017. An explant of 654 heifer mammary gland to study the immune response of the organ. Research in Veterinary

655 Science 114:44-50 DOI: 10.1016/j.rvsc.2017.03.002.

656 Maguer-Satta V, Besançon R, Bachelard-Cascales E. 2011. Concise review: neutral

657 endopeptidase (CD10): a multifaceted environment actor in stem cells, physiological

658 mechanisms, and cancer. Stem Cells 29:389-396 DOI: 10.1002/stem.592. 
659 Maier R, Schmid P, Cox D, Graeme B, McMaster G. 1991. Localization of transforming growth 660 factor-beta1,- beta 2 and -beta 3 gene expression in bovine mammary gland. Molecular and 661 Cellular Endocrinology 82:191-198 DOI: 10.1016/0303-7207(91)90031-M.

662 Martignani E, Eirew P, Accornero P, Eaves C, Baratta M. 2010. Human milk protein production 663 in xenografts of genetically engineered bovine mammary epithelial stem cells. PLoS ONE 5: 664 e13372 DOI: 10.1371/journal.pone.0013372.

665 Massagué J. 1998. TGF-beta signal transduction. Annual Review of Biochemistry 67:753-791 666 DOI: 10.1146/annurev.biochem.67.1.753.

Mroue R, Inman J, Mott J, Budunova I, Bissell M. 2015. Asymmetric expression of connexins between luminal epithelial- and myoepithelial- cells is essential for contractile function of the mammary gland. Developmental Biology 399: 15-26 DOI: 10.1016/j.ydbio.2014.11.026.

667

668

669

670

671

672

673

674

675

676

677

678

Palin M-F, Farmer C, Duarte C. 2017. Triennial lactation Symposium/BOLFA: adipokines affect mammary growth and function in farm animals. Journal of Animal Sciences 95:5689-5700 DOI:10.2527/jas2017.1777.

Pallegar N, Garland C, Mahendralingam M, Viloria-Petit A, Christian S. 2018. A novel 3dimensional co-culture method reveals a partial mesenchymal to epithelial transition in breast cancer cells induced by adipocytes. J Mammary Gland Biol Neoplasia. In Press. DOI:

10.1007/s10911-018-9420-4.

679

680

681

682

683

684

Musters S, Coughlan K, McFadden T, Maple R, Mulvey T, Plaut K. 2004. Exogenous TGF- $\beta 1$ promotes stromal development in the heifer mammary gland. Journal of Dairy Science 87:896904 DOI: $10.3168 / \mathrm{jds}$. S0022-0302(04)73234-8.

Nguyen A, Pollard J. 2000. Transforming growth factor $\beta 3$ induces cell death during the first stage of mammary gland involution. Development 127: 3107-3118 PMID:10862748.

Nickerson S, Akers R. 2011. Mammary gland | anatomy. In: Fuquay J, ed. Encyclopedia of Dairy Sciences. $2^{\text {nd }}$ ed. San Diego: Academic Press. 328-337.

Pai V, Horseman N. 2011. Mammary Gland Involution: events, regulation and influence on breast disease. In: Carrasco J, Mota M, eds. Endothelium and epithelium: composition, functions and pathology. $1^{\text {st }}$ ed. Cincinnati: Nova Science Publishers. 247-284.

Park H, Lee W, Jeong H, Song H. 2016. regeneration of bovine mammary gland in immunodeficient mice by transplantation of bovine mammary epithelial cells mixed with Matrigel. International Journal of Stem Cells 9:186-191 DOI: 10.15283/ijsc16044.

Perruchot M, Arévalo-Turrubiarte M, Dufreneix F, Finot L, Lollivier V, Chanat E, Mayeur F, Dessauge F. 2016. Mammary epithelial cell hierarchy in the dairy cow throughout lactation. Stem Cells and Development 25:1407-1418 DOI: 10.1089/scd.2016.0098. 
685 Phan S. 2008. Biology of fibroblasts and myofibroblasts. Proceedings of the American Thoracic

686 Society 5:334-337 DOI:10.1513/pats.200708-146DR.

687 Plath A, Einspanier R, Peters F, Sinowatz F, Schams D. 1997. Expression of transforming 688 growth factors alpha and beta-1 messenger RNA in the bovine mammary gland during different 689 stages of development and lactation. Journal of Endocrinology 155:501-511 DOI:

690 10.1016/S0301-6226(97)00072-9.

691 Prosser C, Davis S, Farr V, Moore L, Gluckman P. 1994. Effects of close-arterial (external 692 pudic) infusion of insulin-like growth factor-II on milk yield and mammary blood flow in 693 lactating goats. Journal of Endocrinology 142:93-99 PMID: 7964289.

694

695

696

697 Roarty K, Serra R. 2007. Wnt5a is required for proper mammary gland development and TGF698 beta-mediated inhibition of ductal growth. Development 134:3929-3939 DOI:

699 10.1242/dev.008250.

700 Safayi S, Korn N, Bertram A, Akers R, Capuco A, Pratt S, Ellis S. 2012. Myoepithelial cell 701 differentiation markers in prepubertal bovine mammary gland: effect of ovariectomy. Journal of 702 Dairy Science 95:2965-2976 DOI: 10.3168/jds.2011-4690.

703 Sechen, S. 2013. Bovine Somatotropin (bST) - Possible increased use of antibiotics to treat 704 mastitis in cows. Food and Drug Administration. Available at:

705 https:/www.fda.gov/downloads/AnimalVeterinary/SafetyHealth/ProductSafetyInformation/UC

706 M383073.pdf (accessed May 14, 2018).

707 Singh K, Dobson J, Phyn C, Davis V, Farr A, Molenaar A, Stelwagen K. 2005. Milk

708 accumulation decreases expression of genes involved in cell-extracellular matrix communication 709 and is associated with induction of apoptosis in the bovine mammary gland. Journal of Dairy

710 Science 98:67-68. DOI: 10.1016/j.livprodsci.2005.10.016.

711 Tucker H. 2000. Hormones, mammary growth, and lactation: a 41-year perspective. Journal of 712 Dairy Research 83:874-878 DOI: 10.3168/jds.S0022-0302(00)74951-4.

713

714 The UniProt Consortium. 2017. UniProt: the universal protein knowledgebase. Nucleic Acids

715 Research 45:D158-D169 DOI: 10.1093/nar/gkw1099.

716

717 Weaver V, Lelièvre S, Lakins J, Chrenek M, Jones J, Giancotti F, Werb Z, Bissel M. 2002. $\beta 4$

718 integrin-dependent formation of polarized three-dimensional architecture confers resistance to

719 apoptosis in normal and malignant mammary epithelium. Cancer Cell 2:205-216 PMID:

72012242153. 
721 Woodward T, Dumont N, O'Connor-McCourt M, Turner J, Philip A. 1995. Characterization of 722 transforming growth factor- $\beta$ growth regulatory effects and receptors on bovine mammary cells. 723 Journal of Cellular Physiology 165:339-348 DOI: 10.1002/jcp.1041650215.

724 Woodward J, Rennie I, Burn J, Sisley K. 2005. A potential role for TGFbeta in the regulation of 725 uveal melanoma adhesive interactions with the hepatic endothelium. Investigative

726 Ophthalmology \& Visual Science 46:3473-3477 DOI: 10.1167/iovs.04-1311.

Xu J, Lamouille S, Derynck R. 2009. TGF-beta-induced epithelial to mesenchymal transition. Cell Research 19:156-172 DOI: 10.1038/cr.2009.5.

Zarzyńska J, Gajewska M, Motyl T. 2005. Effects of hormones and growth factors on TGF- $\beta 1$

730 expression in bovine mammary epithelial cells. Journal of Dairy Research 72:39-48 DOI:

$731 \quad 10.1017 / \mathrm{S} 0022029904000639$.

732

733

734

735

736

737

738

739

740

741

742

743

744

745

746

747

748

749

750

751

752

753
Zarzyńska J, Gajkowska B, Wojewódzka U, Dymnicki E, Motyl T. 2007. Apoptosis and autophagy in involuting bovine mammary gland is accompanied by up-regulation of TGF-beta1 and suppression of somatotropic pathway. Polish Journal of Veterinary Sciences 10:1-9. PMID: 17388018 .

Zarzyńska J, Motyl T. 2005. Dissimilar effects of LY 294002 and PD 098059 in IGF-I- mediated inhibition of TGF-beta1 expression and apoptosis in bovine mammary epithelial cells. Journal of Physiology and Pharmacology 56:181-193. PMID: 16077202.

Zavizion B, Gorewit RC, Politis I. 1995. Subcloning the MAC-T bovine mammary epithelial cell line: morphology, growth properties and cytogenetic analysis. Journal of Dairy Science 78:515527 DOI: $10.3168 /$ jds.S0022-0302(95)76662-0.

Zavizion B, van Duffelen M, Schaeffer W, Politis I. 1996. Establishment and characterization of a bovine mammary epithelial cell line with unique properties. In Vitro Cellular \& Developmental Biology-Animal 32:138-148 DOI: 10.1007/BF02723679.

Zhang H, Bennett J, Smith K, Sunil N, Haslam S. 2002. Estrogen mediates mammary epithelial cell proliferation in serum-free culture indirectly via mammary stroma-derived hepatocyte growth factor. Endocrinology 143:3427-3434 DOI: 10.1210/en.2002-220007.

Zhang Y. 2009. Non-Smad pathways in TGF- $\beta$ signaling. Cell research 19:128-139 DOI:10.1038/cr.2008.328.

Zhao S, Gao Y, Xia X, Che Y, Wang Y, Liu H, Sun Y, Ren W, Han W, Yang J, Lei L. 2017. TGF-b1 promotes Staphylococcus aureus adhesion to and invasion into bovine mammary fibroblasts via the ERK pathway. Microbial Pathogenesis 106:25-29 DOI: 10.1016/j.micpath.2017.01.044. 


\section{Table 1 (on next page)}

Effect of hormones on TGF $\beta 1$ expression in BME-UV1 and MAC-T cells 


\begin{tabular}{|c|c|c|}
\hline \multirow[t]{2}{*}{ Hormone } & \multicolumn{2}{|c|}{ Cell Lines } \\
\hline & MAC-T & BME-UV1 \\
\hline Growth Hormone & No significant effect & $\begin{array}{c}\downarrow \text { TGF } \beta 1 \text { protein levels in } \\
10 \% \text { FBS but } \uparrow \text { TGF } \beta 1 \\
\text { protein levels in } 0.5 \% \text { FBS }\end{array}$ \\
\hline Somatostatin & No significant effect & $\begin{array}{c}\uparrow \mathrm{TGF} \beta 1 \text { protein levels in } \\
10 \% \mathrm{FBS}\end{array}$ \\
\hline
\end{tabular}

1 Table summarizes select data from Zarzyńska, Gajewska \& Motyl, 2005.

2

3 


\section{Table 2(on next page)}

Comparison of MAC-T and BME-UV1 luminal and basal marker expression in relation to one another 


\begin{tabular}{|c|c|c|}
\hline & MAC-T & BME-UV1 \\
\hline CD10 Expression & Absent & Present \\
\hline CD49f Expression & Present (higher in ADH) & Present \\
\hline EpCAM Expression & Present (lower in ADH and ULA) & Present \\
\hline CK14 Expression & Present & Absent \\
\hline CK19 Expression & Absent & Present \\
\hline ALDH Activity (ADH) & Lower & Higher \\
\hline
\end{tabular}

1 Table summarizes select data from Arévalo Turrubiarte et al., 2016. Unless otherwise indicated, 2 the expression indicated reflects results obtained under three different culture conditions:

3 standard adhesion (ADH), ultralow adherence (ULA) and Matrigel $^{\mathrm{TM}}$. 


\section{Figure 1}

\section{Canonical TGF $\beta$ signalling}

TGF $\beta 1$ binding to the constitutively active T $\beta R$ II Ser/Thr kinase promotes its re-localization and the formation of a tetrameric complex with the T $\beta R I$, leading to phosphorylation and activation of T $\beta R I$ ser/thr kinase. The latter in turn phosphorylates the Smad2/3 transcription factors, permitting their association with Smad4. The Smad2/3/4 complex translocates to the nucleus where in association with other transcription factors (not shown) modulates the expression of target genes that, among other effects, promote apoptosis and inhibit cell proliferation in normal mammary epithelial cells.

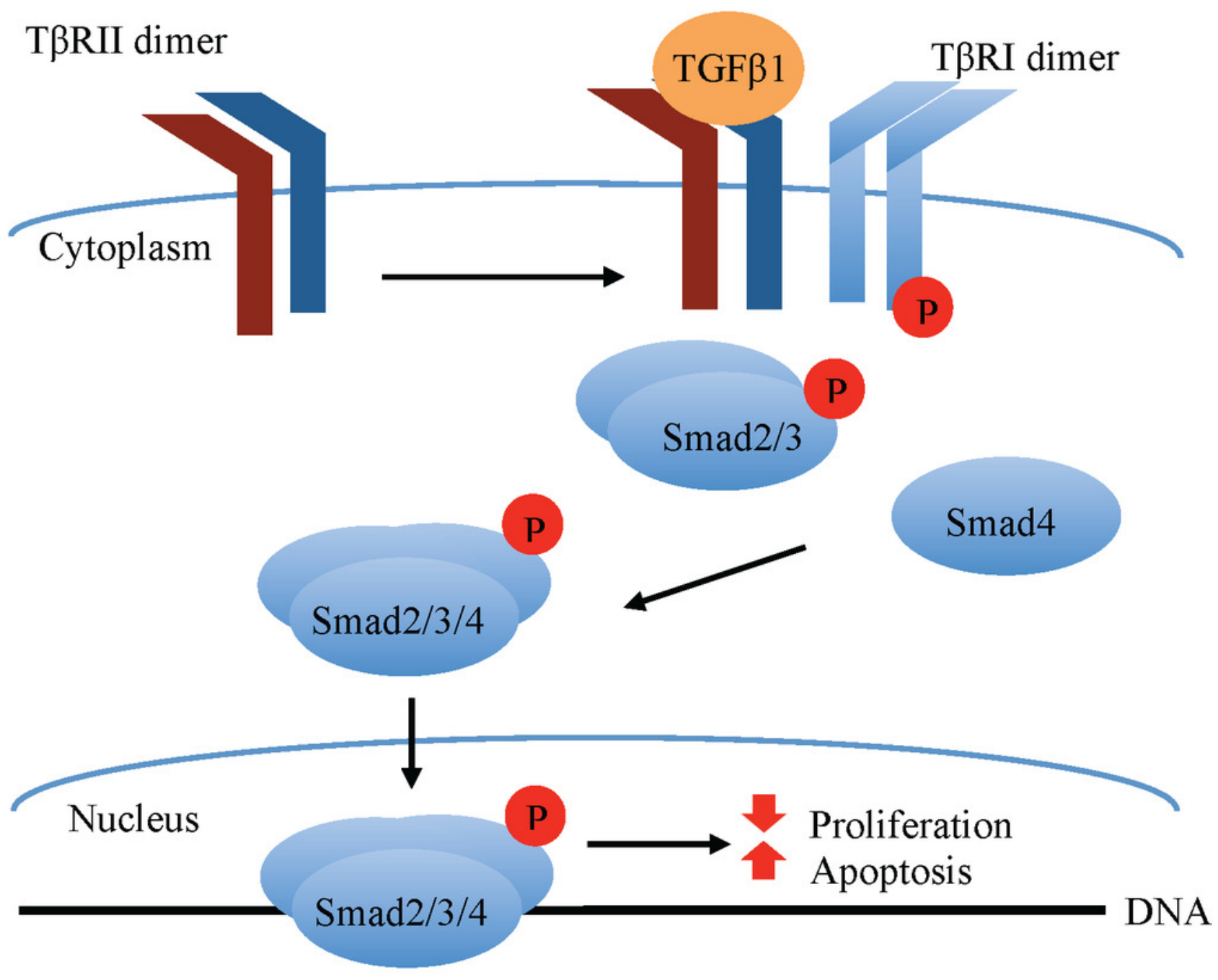




\section{Figure 2}

Crosstalk between TGF $\beta 1$ and the somatotropic pathway

TGF $\beta 1$ and IGF-1 repress each other' signalling and consequent celular response (apoptosis and survival, respectively) in bovine mammary epithelial cells. This involves the inhibition of TGF $\beta 1$ expression by IGF-1 and the blockade of IGF-1 signalling activation by TGF $\beta 1$-induced IGF binding proteins (IGFBPs). The exact mechanisms by which these occur have not been described for bovine mammary epithelium.

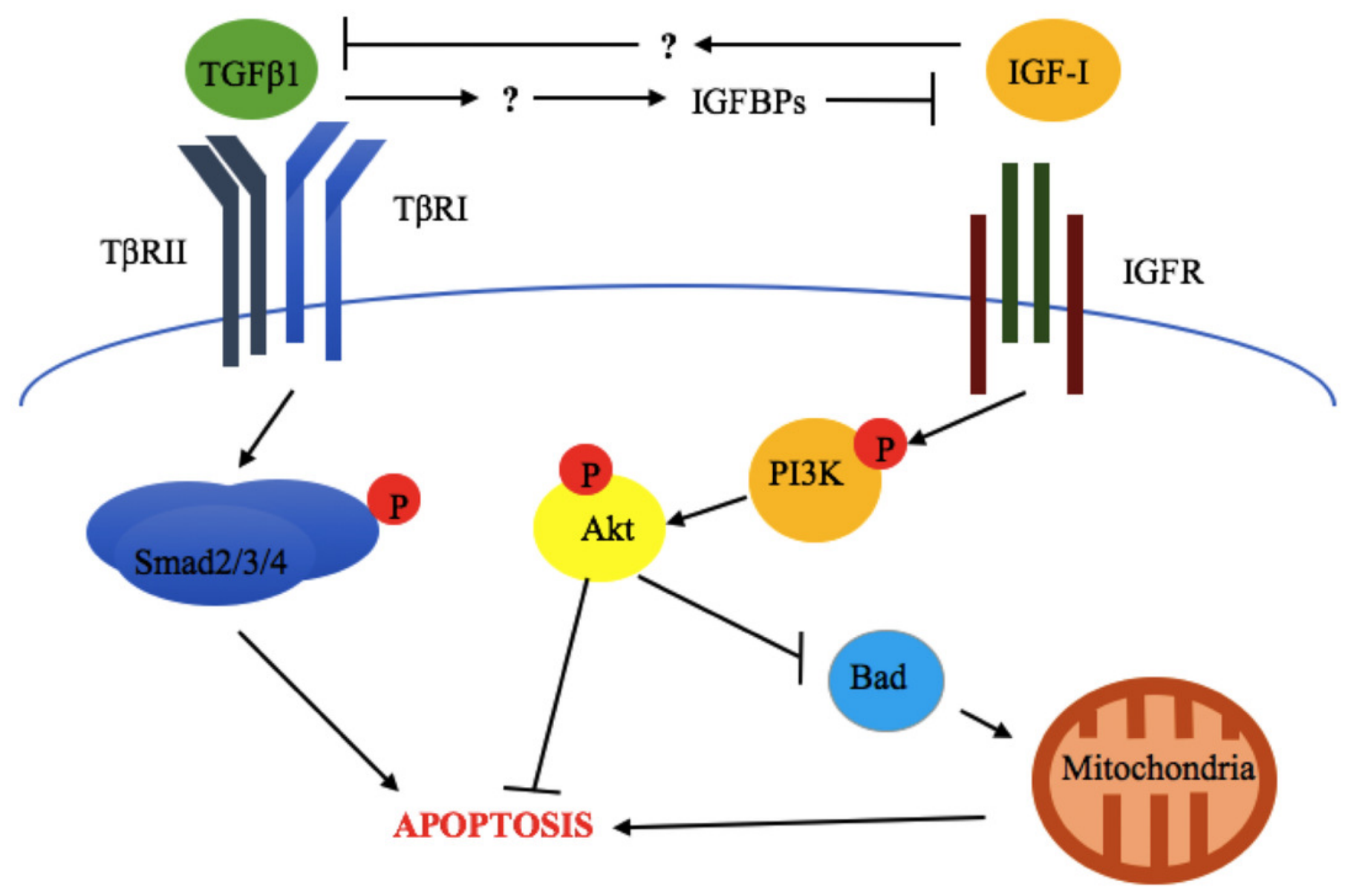

